\title{
„Pocity plotu"1: teritoriální (re)produkce, normativita a ne/viditelnost ve veřejném prostoru panelového sídliště ${ }^{2}$
}

\author{
"The Sense of the Fence": Territorial (Re)production, Normativity \\ and In/visibility in the Public Spaces of Modernist Housing Estates
}

Michal Lehečka

\begin{abstract}
This article focuses on the material components of public space, e.g. walls, fences, and grids, and shows how they can be seen from an analytical point of view as active components of the (re) production of space. Based on illustrative cases from my long-term fieldwork in a modernist housing estate, I explore what roles physical barriers play in the constitution of various (in)visible relations between the inhabitants, spatial practices and, of course, the socio-material environment. For this purpose I operationalise and further extend Kärrholm's concept of "territorial (re)productions". This approach allows me to grasp processuality and relativity as well as the effects of constant (re)production of territoriality in the micro-context of the post-socialist modernist space. From this point of view, both human and nonhuman components (individuals, public space amenities, natural entities) of the reality are in continuous interaction. The housing estate is (re)produced by individual, collective and often (in)visible manifestations of Right to the City. These manifestations mirror the assemblage that is spatio-temporally embedded in the hybrid interplay between residual principles of socialist modernist urbanism and socialist housing policies and the economic transformation, renaissance of private ownership and individualism which emerged after 1989. Altogether these regimes are appropriated through the processes of everyday territorial (re) productions in socio-material space.
\end{abstract}

KEY WORDS space, modernist housing estate, barriers, territorial (re)production, right to the city

„Účko, srdce sídliště, cca 15:00 hodin odpoledne, druhá polovina listopadu, je jen lehce nad nulou. Další terénní práce na zdejším hřišti. Chodím sem na třetí, protože v tolik hodin hřišsě opouští školní družina a potom je až do šesti hodin otevřeno pro děti z okolí. Už zdálky, ostatně jako vždycky, slyším povyk. Pohybuje se tu třicet až čtyřicet dětí ve věku od 5 do 15 let. Po příchodu k hřišti zpozoruji, že některé děti už jsou uvnitř, což mě vede $\mathrm{k}$ domněnce, že družina nechala dětem hřiště

Sociální studia / Social Studies 1/2019. S. 57-77. ISSN 1214-813X.

1 Termín je vypůjčen z názvu písně hudebního uskupení Už jsme doma.

2 Tento výstup vznikl v rámci projektu Specifického vysokoškolského výzkumu 2017-260 470. 
otevřené. U vstupní brány na oplocené hřiště ovšem zjišt’uji, že je branka zavřená. Družina tu dnes evidentně nebyla. Místní děti mne už dobře znají, takže ke mně ihned běží, nebot' vědí, že s sebou v batohu nosím věci na sport a hry - míče, náčiní, křídy, gumu a podobně.

Nemůžu se dostat dovnitř. Po chvilce přichází správce, aby otevřel branku. Diví se, co se stalo se zámkem. Vidí, že jazýček je celý zkřivený, takže musí vytrhnout dveře. K mému překvapení nepátrá po viníkovi.

Jsem ze zničení zámku dost rozladěn, protože vím, že každá taková zničená věc nebo závada povede $\mathrm{k}$ dalšímu napětí mezi úředníky z radnice, školou, provozovatelem hřiště a místními uživateli, především dětmi. Dost přísně se dětí ptám, kdo a proč to udělal. Většina tvrdí, že už „to bylo“, když přišly. Některá ale obviňují Špalíka s Bobešem, asi desetileté chlapce. Ti se tomu vehementně brání. Po pachateli dál nepátrám, protože vím, že se stejně nikdo nepřizná. Snažím se jim jen vysvětlit logiku přemýšlení „ostatních“ o tom, že někdo něco zničí, nebo vleze někam, kam nesmí. I přes (nejen) moje několikaměsíční stížnosti u správce a př́slušných úředníků na radnici, že najatý správce hřiště otevírá velmi nespolehlivě a nepravidelně, což vede k tomu, že děti a mládež často prééézají oplocení hřiště, jež má zhruba čtyři metry na výšku, se situace nezlepšuje. Hřiššě, ač propagováno jako v zásadě veřejné, tak reálně nefunguje. Jakýkoli komerční pronajímatel má před místními dětmi a mládeži přednost. Naštěstí pronájmů moc není. I kdyby, děti stejně považují hřriště za svoje.

Děti neustále žadoní o míče, končím tedy se svými apely a otevírám krosnu. Špalík se jako vždy cpe nejvíc dopředu, protože míče mám s sebou jen tři. Pokřikuje: „Pujč mi fotbalovej míč, pujč ho mně!"“Zpozoruju, že má na bundě a na ruce docela dost krve. Ptám se ho, co dělal. Odpovídá: „To mám z toho, jak jsem páčil ten debilní zámek...“ (přepis z terénního deníku, 19. 11. 2015)

Plot, zed', obecně překážka oddělující dva prostory, je vždy strukturován a zároveň strukturuje způsoby své (re)produkce. Předmětem tohoto etnografického textu je pokus o představení specifických režimů a praxí, které poukazují na principy a způsoby teritorializace prostoru bez toho, že by musely být do popředí stavěny např́íklad mocenské, třídní či etnorasové perspektivy. Hlavní linie argumentace sleduje symetrizující logiku, podle které proces produkce prostoru (Lefebvre 1991) vykazuje podobu „zmnoženého přivlastnění“ (Kärrholm 2012; Stulíková 2015), ve kterém vstupují do hry lidské i ne-lidské, tedy sociální a materiální fragmenty aktuální lokální konfigurace prostředí. (Fyzické) hranice prostoru se tedy nejen překrývají, ale i rytmizují, temporalizují, zpochybňují, negují či z(ne)viditelňují. Zároveň se v nich vždy odráží jistá vztahovost a asymetričnost, která dokazuje, že symetrie je pouze zř́dka, jestli vůbec někdy, skutečně symetrická (Pels 1996: 281). V souladu s tím i má snaha o jistou „symetrizaci“, tedy pokus o analytické propojení některých na první pohled nesouladných realit socio-materiálního světa, vyplývá z potřeby zdưraznit a zároveň nahlédnout asymetrickou povahu prostorových a mocenských vztahů (Stöckelová a Brož 2015: 17) a díky odhalení těchto asymetrií zachytit některé prostorové produkce optikou fundamentálních - a bytostně socio-materiálních - projevů práva na město (srov. Lefebvre 1996, Harvey 2008, 2012).

Na tomto místě je nutno v krátkosti osvětlit pojetí symetrie, jež se pokouším aplikovat např́ič následujícím textem. Symetrické přístupy v sociálních vědách mají svoji oporu například ve starších textech Bruna Latoura (např. Latour 2003). Latour mimo jiné osvětluje asymetrický přístup sociálních vědců k sociálním a př́rodním komponentům zkoumaných fenoménů. Latourova kritika vychází z tvrzení, že sociální vědy s př́rodou a materialitou pracují v intencích jednolité (především západní) prŕírodní vědy (Latour 2003, Stöckelová a Brož 
2015, Stulíková 2015), kdežto sociální svět hodnotí a nahlíží na základě kulturního relativismu a diverzity. Symetrizace tak znamená snahu alespoň částečně narovnat ontologickou dysbalanci mezi sociální, přírodní, materiální, ekonomickou či jakoukoli další pozorovatelnou sférou konfigurací. Tato sada principů tak umožňuje osvětlit často opomíjenou povahu vztahovosti a provázanosti lidských a ne-lidských skutečností. Z takto ukotveného analytického hlediska právě materiální a sociální komponenty sídliště nemohou existovat odděleně. Ploty, prostorové překážky, př́rodní prvky či parametry fungování veřejných prostranství tak v interakci s lidskou aktivitou (jednáním a praktikami) spoluutvářejí složité a neustále se měnící prostorové konfigurace.

V souladu s tím, co říká v rozhovoru s Terezou Stöckelovou a Lud'kem Brožem sociolog Zdeněk Konopásek, nahlížím zkoumaný socio-materiální výřez světa s vědomím asymetričnosti pozorované skutečnosti (Brož a Stöckelová 2015: 121). Nesnažím se tudíž o jakoukoli nestrannost, ale o zachycení a osvětlení nerovnovážností, ve kterých se v určitých momentech mohou i nemusejí odrážet mocenské povahy a vztahy jednotlivých aktérů a komponentů konkrétních prostorových konfigurací. I proto $\mathrm{v}$ textu pracuji s přidruženými pojmy asymetrie, symetrizace, asymetrizace. Ty nemají poukazovat na to, že někde existuje nějaká ideální symetrie, ke které je třeba směřovat, nebo se jí naopak vyhýbat. Jejich smyslem je naopak poukázat na pozicionalitu, procesualitu, nestálost a proměňující se perspektivu nahlížení jednotlivých vztahů ve studovaných konfiguracích. Jinými slovy, takto odvozené pojmy poukazují na to, že ve snaze o adekvátnější přístup ke skutečnosti je v některých situacích analyticky užitečnější hledání vítězů a poražených alespoň na chvíli ponechat stranou a soustředit se na podstatu samotných interakcí.

\section{Kontext výzkumu a výzkumná pozice}

Data, jež dala vzniknout tomuto textu, byla vytvořena během výzkumu prováděného $v$ letech 2014-2017 na větším pražském periferním sídlišti, které je v textu nazváno Dlouhé Lávky. Klíčovou roli v analýze hraje také pomístní název Účko, který označuje specifickou lokalitu sídliště, sousedství, kde je možno pozorovat projevy sociální marginalizace a jež je obyvateli okolních částí sídliště stigmatizováno a označováno jako ghetto. Takto definovanou lokalitu samozřejmě nelze uměle oddělovat od zbytku sídliště, proto sleduji působnost Účka v rámci sídliště jako celku.

Text popisuje moji současnou interpretaci nahlížení (re)produkce krajiny sídliště na př́ikladu tř́ prípadů prostorových komponentů, jejichž proměny a vývoj v čase jsem mohl v sídlišti pozorovat. Tyto komponenty vhodně ilustrují současnou dynamiku fungování prostoru modernistického města. Specificky se zaměřuji na proces přivlastňování veřejného prostoru odrážející se v procesu (re)produkce prostorových diskontinuit, bariér a překážek. Jedná se o mřriže, zdi a ploty, tedy hmotné prostředky strukturace prostoru, $v$ jejichž působnosti, konfiguracích, využití i symbolických významech je možno sledovat dynamiku sídliště jako strukturované krajiny překrývajících se teritorialit.

Moje prrítomnost $\mathrm{v}$ lokalitě probíhala pod hlavičkou aplikovaného antropologického výzkumu. Dva roky jsem na Dlouhých Lávkách působil jako komunitní koordinátor, tzn. pracovník spojující roli výzkumníka a „mediátora potřeb“ místních obyvatel směrem k lokálním 
organizacím a institucím. Po skončení projektu jsem ještě zhruba rok prováděl v místě akademický výzkum v rámci disertační práce. Většina dat představených $\mathrm{v}$ následujícím textu tak vznikla během zúčastněného pozorování kombinovaného s mnoha dalšími metodami - neformálními rozhovory, polostrukturovanými rozhovory, pořizováním vizuálních materiálů týkajících se každodenního života obyvatel i monitorování prostoru a materiální kultury sídliště.

Vzhledem $\mathrm{k}$ povaze $\mathrm{v}$ textu představovaných teritoriálních fenoménů pochází většina představených analytických tvrzení z pozorování a ze studia některých režimů materiální kultury sídliště. V lokalitě jsem samozřejmě realizoval i desítky rozhovorů. Na některé jevy týkající se teritorializace se však aktérů nešlo jednoduše dotazovat, či lépe řečeno, bylo je možno pouze pozorovat a rekonstruovat, protože jsou z mnoha důvodů, jež osvětlím níže, v podstatě neviditelné. Důležitou sféru mých výzkumných aktivit tak představoval „archeologicky“ zaměřený monitoring prostoru sídliště. $Z$ vyšlapaných pěšin, přítomnosti odpadků a dalších odhozených pozůstatků či stavu a podoby místního mobiliáře (ploty, koše, lavičky, vybavení hřišt') jsem dotvářel a přetvářel mentální mapu teritorializace prostoru Dlouhých Lávek.

Perspektivu pozorovatele jsem nejsilněji překračoval během prvních dvou let výzkumu, kdy jsem na Dlouhých Lávkách po několik měsíců působil také jako tzv. animátor veřejnoprostorových aktivit (viz úvodní pasáž textu) pro místní neziskovou organizaci zabývající se sociální prací a terénními programy pro děti a mladistvé.

Tato asambláž výzkumně-pracovních rolí mi umožnila stát se téměř insiderem. Zejména animační činnost pro děti (sportování, hraní her, pořádaní závodů a kulturních programů ve spolupráci prímo s dětmi), tedy stávání se tak trochu dítětem, mi poodkrylo jinak velmi těžko pozorovatelné sféry socio-materiálního života sídliště. Po celou dobu tu ale byly i moje další role, jež jsou ilustrovány v úvodní terénní poznámce: role výzkumníka-outsidera, sociálního pracovníka, ale i role disciplinační, vyplývající z pozice, věku i z etnické př́islušnosti. Jakožto pracovník balancující mezi terénním výzkumem, sociální prací a sídlištním policy-makingem jsem představoval hybridní a často neuchopitelnou postavu. Podle okolností jsem byl stř́davě nucen přecházet $\mathrm{z}$ pokusů o ustavování egalitářského módu do asymetrických, mocensky vyhraněných pozic, což zpětně hodnotím jako jedno z největších úskalí i předností mé pozice. I přes tuto nejednoznačnost jsem se pro mnohé po nějakém čase stal př́telem, kamarádem, Gandalfem $^{3}$, který aktivně spoluvytvářel každodennost Dlouhých Lávek na mnoha úrovních, a mé aktivity, praktiky i moje neskrývaně problematická pozice zásadním způsobem ovlivňovaly (re)produkci prostoru.

Právě díky tomu, že jsem pozoroval i spoluutvářel hybridní proměny, které často měly jasný mocenský podtext, je mým zájmem skrze symetrizaci poukázat na proměňující se asymetrie, které oslabují pocit jakési vágní a nejasné rovnováhy. Proto především v závěrečné kapitole tohoto textu zvýznamňuji dopad teritorializace na pozicionalitu a sociální situaci jednoho konkrétního aktéra.

3 Od místních dětí a mladistvých jsem dostal přezdívku Gandalf. Vznikla na základě mé vizáže během výzkumu. Nosil jsem tehdy dlouhé vlasy a plnovous. Zpětným pohledem je až zarážející, jak dobře tato přezdívka vystihuje i jiné sféry mé identity než ty vizuální. Pojmenování podle Gandalfa z Tolkienova světa Středozemě v sobě může nést i rozměr značné nejednoznačnosti a problematičnosti mé osoby $\mathrm{v}$ očích ostatních aktérů. 
Stěžejní roli v tomto textu hraje socio-materiální prostor jednoho z nemladších pražských sídlišt'. Dlouhé Lávky jsou modernistickým městem, jež je poměrně striktně odděleno od okolní zástavby a představuje samostatný urbanistický celek. Pověst sídliště však značně přesahuje jeho prostorové hranice.

Z hlediska vnitřní struktury je sídliště členěno jak urbanisticky, tak lokálními obyvateli do čtyř okrsků. Pomístní názvosloví vychází především ze dvou kritérií: bud' jsou jednotlivé okrsky sídliště odlišovány pomocí římských číslic (Dlouhé Lávky I, II, III, IV), nebo podle důležitých lokalit či názvo̊ škol (Mikojanka, Gagarinka, Kuzněcovka atd.). Nejstarší část sídliště byla vystavěna již na konci 70. let 20. století a od ostatních novějších sousedství je oddělena prostorem městské zeleně. Další dvě části, označované jako II a III, jsou výsledkem výstavby v pozdních 80 . letech 20. století. Součástí těchto lokalit je i Účko. Čtvrtý sídlištní okrsek nesestává z klasické panelové výstavby, nebot’ byl postaven až na přelomu milénia. Nejde tedy o klasickou sídlištní lokalitu, nebot' urbanistická struktura je zde rozdílná a spíše kopíruje blokovou zástavbu ve vnitřním městě.

Z hlediska majetkové struktury bytového fondu sídliště lze konstatovat, že je zde poměrně vysoký počet bytů a objektů vlastněných Magistrátem hlavního města Prahy a příslušnou městskou částí (KPMG 2016) - právě toto specifikum spoluurčuje rozmanitou etnickou strukturu tohoto sídliště. Dlouhé Lávky jsou sídlištěm, které mimo útočiště pro pražskou romskou komunitu, představuje, jako mnohá další sídliště, domov pro vysoký počet osob původem z jiných států. Podíl tzv. non-Czech citizens, tedy osob s přechodným nebo trvalým pobytem, avšak bez českého státního občanství, se zde v roce 2011 pohyboval okolo 13 \% (Němec a Brabec 2015: 19, Přidalová a Ouředníček 2017). Tento procentuální poměr sice v pražském prostředí znamená průměr, množství lokálně sídlících etnik však z Dlouhých Lávek činí sídliště nadprůměrně rozmanité. (Ouředníček a Temelová 2012). Rozmanitost a multikulturnost veřejně propagují a podporují i některé složky místní samosprávy a lokálních odborů státní správy městské části, jíž jsou Dlouhé Lávky součástí.

\section{Účko}

Prostorové členění sídliště a jeho urbanistická skladba vytvářejí prostředí koridorů a bariér. Taková socio-materiální konfigurace vytváří ideální podmínky pro zmnožování praktik, překrývání a vtělování teritorií (srov. Lehečka 2015). Př́́kladem silně ambivalentní oblasti je právě Účko. Tato oblast i přes svůj název nemá jasné hranice a ve zkazkách (především) okolních obyvatel je často tradována jako „cikánov“, „černý srdce Dlouháčư “ či jako no-go zóna. Fakticky se jedná o několik osmi až dvanáctipodlažních panelových bloků propojených dvěma ulicemi a jejich nejbližším okolím. Daleko důležitější než negativní nálepkování však je, že v porovnání s jinými sídlištními lokalitami vykazuje zdejší veřejný prostor známky značné zanedbanosti a neposkytuje místním obyvatelům prŕiliš možností, jak kvalitně trávit čas v exteriéru sousedství. Tato specificky sporá struktura prostoru má tři důležité lokální důsledky: (1) frekventovaný výskyt neporádku nejen kolem kontejnerů směsného odpadu, (2) koncentraci volnočasových aktivit do několika málo lokálních ohnisek (dětská hřiště), (3) podnícení imaginace některých 
jedinců $\mathrm{k}$ tomu využívat i místa, která k trávení volného času nejsou primárně určena (zadní schodiště do jednotlivých domů, poklopy kolektorů, opěrné zdi).

Pověst i stav Účka jsou (re)produkovány také sociální a rozvojovou politikou města. Hlavní město Praha si část zdejšího bytového fondu udržuje jako neoficiální sociální bydlení. Za zmínku stojí, že podíl romských a neromských obyvatel (i když pro toto tvrzení neexistují spolehlivá data), je podle hrubých odhadů učiněných na základě pozorování zhruba vyrovnaný. Míra nezaměstnanosti je - i přes často zmiňovaný vyšší výskyt osob na podpoře - pouze zhruba o 1,5 \% vyšší než celopražský průměr (Němec a Brabec 2015: 23). Statistiky kriminality rovněž nevykazují zásadní odchylky od průměru, snad jen ve výskytu př́ípadů výroby a distribuce drog (viz naprŕ́klad www.mapakriminality.cz). Lokalita je tak mimo nefunkčnosti sociální politiky státu a města na první pohled „konzervována“ i tím, že ji doprovází společenský obraz nebezpečného místa, jež je prostředím tzv. kultury teroru (Bourgois 2003, srov. Taussig 1984), což zjednodušeně znamená, že stigmatizace Účka je prohlubována spíše strachem, lokální segregací a prostou (re)produkcí špatné pověsti, než reálným výskytem nebezpečí (srov. Wacquant 2008).

I proto „demytizující“ statistická data často nemají žádnou zásadní váhu. Pověst Účka zůstává spíše negativní, a to na více úrovních, tedy od stigmatizace konkrétních sousedství až po stereotypy kolující na celopražské úrovni, kdy je negativní nálepkování přenášeno na Dlouhé Lávky jako celek. Status obyvatel problémové čtvrti je tradován i zpochybňován a tím samozřejmě různě (re)produkován i jimi samými. Pověst Dlouhých Lávek je tak napínána na pomyslné šňůřre mezi snahami o vykročení ze stínu své špatné pověsti a hýčkáním negativní pověsti jako hlavního distinktivního znaku sídlištního celku.

Jak už bylo naznačeno, tyto prolínající se režimy se otiskují i v materialitě sídlištního veřejného prostoru. Na jedné straně tu narazíte na opatření normativního, racionalizujícího a optimalizujícího charakteru, jež mají svůj původ právě v touze po destigmatizaci Dlouhých Lávek jako celku. Na druhé straně se setkáte s interně vyjednávanými procesy normativní i neformální (re)produkce a přivlastňování prostoru sídlištních sousedství. Klíčovou roli v tomto systému (re)produkce hrají mimo institucí, organizací, vlastníků a nájemníků dvě specificky (ne)viditelné skupiny uživatelů prostoru: lidé bez domova a mladší obyvatelé sídliště (dětí a dospívajících je na Dlouhých Lávkách v celopražském kontextu mírný nadprůměr; Němec a Brabec 2015: 13). Právě interakce těchto aktérů a hmotných struktur sídlišti udělují specifickou prostorovou dynamiku, čímž jsou hranice Účka i Dlouhých Lávek neustále redefinovány a je tak nastavováno pomyslné zrcadlo normativnímu ,provoznímu řádu““4 veřejných prostranství sídliště.

\section{Teritoriální (re)produkce}

Zdánlivě neproblematické a nevýznamné ploty, zdi a další překážky mohou poukazovat na teritoriální neprůhlednost a napětí v modernisticky strukturovaných prostorech. Ilustrativní

4 „Provozním řádem“ je myšlena konfigurace sestávající z místních i celoměstských vyhlášek regulujících veřejný prostor, ale i nekodifikovaných pravidel fungování veřejných prostranství v určitém místě. 
popis s vypáčenou brankou z úvodu textu ukazuje př́íklad, kdy je teritoriálně produkovaná normativita konkrétního prostoru zpochybňována (re)produkcí alternativních forem přivlastnění.

Teoretická výbava a argumentace textu se pohybuje na pomezí „symetrizujícího“ konceptu „teritoriálních produkcí“ (Kärrholm 2007, 2012: 14) s využitím víceméně klasického sociálně konstruktivistického náhledu na socio-prostorovou distribuci moci v tzv. postindustriálním městě (např. Bourdieu 1990; Castells 1972; Harvey 2000, 2008, 2012; Holston 1989; Lefebvre 1991; Low a Lawrence-Zuniga 2003; Rabinow 1989; Susser 1982). Kombinaci těchto dvou perspektiv volím zejména proto, že oba př́stupy vykazují specifické limity a jejich propojení obohacuje analytickou výbavu textu ve chvílích, kdy je třeba zvážit povahu konkrétních (a)symetrií.

Kärrholmova sada nástrojů pro analýzu veřejného prostoru vychází nejen z idejí prostoru jako sociálního produktu (Lefebvre 1991) a z kategorizace prostorových strategií a taktik z pera Michela De Certeau (1984), ale také z tzv. teritorologie (Brighenti 2010), která se obecně zaměřuje na způsoby vytváření, přetváření a prostupování hranic. Kärrholmův př́stup se tak snaží překlenout vědění vzniknuvší v souvislosti s tzv. prostorovým obratem v sociálních vědách a zasadit je do nového epistemologického rámce. V českojazyčném prostředí je doposud využila především Vlasta Stulíková v kontextech vážících se k bezdomovectví. Právě na její interpretaci tento text částečně reaguje a v určitém smyslu i navazuje (srov. Stulíková 2015). ${ }^{5}$

Kärrholm pracuje s teritoriem mimo jiné jako s procesem - sítí prostorově vymezených, kontrolovaných a zvýznamňovaných socio-materiálních praktik, které jsou (ne)viditelně, avšak konstantně vepisovány do prostorových konfigurací (Kärrholm 2012: 2). (Ne)viditelnost $\mathrm{s}$ předponou $\mathrm{v}$ závorce $\mathrm{v}$ tomto kontextu symbolizuje především dvojaký charakter zachytitelnosti daných jevů - teritoriální produkce jsou v terénu zpravidla různě viditelné či skryté. Stejně tak jsou různě viditelní či nenápadní původci těchto produkcí. Jinými slovy, (ne) viditelnost záleží na perspektivě pozorujícího, ta vyplývá z jeho pozice v aktuální prostorové konfiguraci.

Dle Mattiase Kärrholma se proces teritorializace prostoru odehrává primárně ve fluidním poli mezi různými druhy produkcí: strategiemi, taktikami ${ }^{6}$, přivlastňováním (apropriacemi) a spojováním (asociacemi) (Kärrholm 2007: 441; Stulíková 2015: 74). První dva druhy produkcí jsou v jeho pojetí považovány za intencionální, naopak přivlastňování a spojování definuje Kärrholm jejich bezděčností. Teritoriální strategie v tomto kontextu představují konkrétní a často formální snahy o vymezení a nárokování prostoru, jež jsou činěny s určitou distancí,

5 Vlasta Stulíková ve svém textu pracuje s teritoriálními produkcemi v kontextu „sdíleného prostoru“, čímž se snaží demonstrovat určitou vzájemnost a fundamentální inkluzivitu veřejných prostranství. Pro potřeby mého textu zůstávám u využití pojmů veřejný prostor a veřejná prostranství, nebot' dle mého názoru lépe ilustrují určitou normativitu a konfliktnost jejich povahy i to, jak jsou v různých kontextech produkovány.

$6 \quad$ Pro Kärrholma jsou strategie a praktiky na rozdíl od De Certeaua (1984) daleko více provázané a nedají se rozlišit na apriorní preskripce, tedy strategie od stolu a taktiky vytvářené v praxi (Kärrholm 2012: 18). Strategie praktiky mohou existovat současně a vzájemně se překrývat. 
tedy tak trochu mimo (re)produkovaný čas a prostor. Ilustrativním příkladem může být například vytvoření provozního řádu hřiště na Dlouhých Lávkách, či outsourcing správy místního sportovního areálu. Teritoriální taktiky představují normativní produkce, jež jsou činěny přímo na místě, tedy např́iklad prosazování provozního řádu hřiště jeho správcem či vymáhání nočního klidu ze strany městské policie. Rovina teritoriálního přivlastňování podle Kärrholma představuje především opakované a konzistentní procesy produkce teritoria z jeho socio-materiálních komponent. Tento proces není cílený, formalizovaný a podle autora nemusí být ani uvědomovaný. Ovšem rozhodnutí o vědomosti a bezděčnosti těchto produkcí je přinejmenším velmi sporné. Míru intencionality je třeba vždy vyvozovat z kontextu situace. Př́kladem může být vybírání popelnic bezdomovci nebo scházení se v prostorech, které k tomu nejsou primárně určeny. Takto produkované teritorium je důsledkem zaběhlých, všedních a nutných činností. Poslední komponent produkce, teritoriální spojování, vyjadřuje využívání určitého místa pro určité funkce, jež vyplývají z konkrétních konvencí a pravidel. Lokální projevy výše zmíněných teritoriálních produkcí vytvářejí teritoriální komplexitu - neustále se reprodukující a vyvažující krajinu vztahů v prostoru (Kärrholm 2012: 137-138).

Důraz na komplexitu u Kärrholma vychází z pojetí socio-materiální prostorovosti jako svého druhu ekosystému (Kärrholm 2007, 2012), k čemuž dlouhodobě směřují i jiní autoři zabývající se městem a prostorem (srov. Low 2017; Low a Lawrence-Zuniga 2003; Low, Taplin a Scheld 2005; Stevens 2008). Environmentální metafora v sobě obsahuje specifické pojetí rovnováhy, které vychází z předpokladu, že prostředí není striktně pozičně fixováno, ale existují v něm sítě vztahů, které svými (re)produkcemi, pohyby a proměnami tendují k (re) stabilizaci prostředí.

Pro osvětlení tohoto pojetí teritoriality a ve snaze vyhnout se obvinění z naturalizace socio-materiálního světa je důležité zmínit, že Kärrholm navazuje na Browna a Capdevilovou, kteří tvrdí, že proces teritorializace nestojí primárně na instinktech, ale na konstantní činnosti a demonstraci teritoriality:

„Proč je pojem teritorium tak přiléhavý: protože řád a jistota, jež přináší, nejsou statické, ale naopak pohyblivé fenomény. Podobně jako prostor označkovaný teritoriálním živočichem, se teritorium konstantně přesouvá a je neustále přeznačkováváno a (re)prezentováno různými způsoby. Úsilí vynaložené takovými teritoriálními stvořeními nám navíc ukazuje značné obtíže, jež jsou spojeny s udržitelností samotného procesu přeznačkovávání.“ (Brown a Capdevila 1999: 41-42, pracovní překlad autora)

Sluší se ještě dodat, že pod „,prací“ a „demonstrací teritoriality“ se skrývá prostý fakt: proces teritorializace je podmíněn obecnou skutečností existence pohybu. Na základě těchto tvrzení se v následujícím textu pokusím i časoprostor sídliště představit jako neustálý pohyb, jako nekonečně se (re)produkující sít' vztahů socio-materiální povahy.

Kärrholmovo rozlišení na teritoriální strategie, taktiky, přivlastnění a spolupráce může být v mnoha ohledech zavádějící, nebot' navozuje dojem oddělenosti a oddělitelnosti jednotlivých produkcí. Jestliže je Kärrholmovým primárním zájmem poukázat na tekutost, proměnnost a překryv vymezených způsobů (re)produkcí, je nabíledni přistupovat k teritorializaci s vědomím, že konkrétní modality produkce mohou spadat do všech kategorií zároveň, 
přebíhat mezi nimi, stále unikat zařazení atd. I z toho důvodu budu pro potřeby další interpretace využívat především centrální pojem teritoriální produkce, pozměněný do formy teritoriální (re)produkce. Pojem (re)produkce s předponou re- v závorce využívám zejména, proto, že dle mého názoru nejlépe ilustruje fakt, že jakákoli produkce nemusí být jen tvưrčím aktem, ale zpravidla z něčeho vzniká, tedy vyplývá z předchozích konfigurací, z plynutí času $\mathrm{i}$ proměn prostoru. $\mathrm{V}$ př́padech, kdy je to $\mathrm{z}$ kontextu jasné a zjevné, přistupuji $\mathrm{k}$ užití pojmů podř́żených. Jinými slovy, jednotlivé kategorie je sice teoreticky možno poměrně jednoduše rozlišit a oddělit, tváríi $\mathrm{v}$ tvář konkrétním produkcím - pohybům, procesům, praxím či jednání - nelze vždy jednoznačně zhodnotit, které komponenty (re)produkce jsou více či méně př́tomny, natožpak které jsou vědomé či bezděčné.

\section{Distribuce moci a „právo na město“}

Dalším problematickým bodem jsou samožrejmě limity samotné symetrizace. Tato snaha odstoupit od často ne zcela produktivního antropocentrického pohledu na studované reality sice $\mathrm{v}$ případě teritorializace přináší velmi produktivní zjištění, nicméně skýtá nebezpečí týkající se upozadění subjektivního, morálního či mocenského hodnocení některých situací ze strany individuálních aktérů. Jinými slovy, metodu sledování teritoriálních produkcí je třeba zpětně obohatit o to, co často cíleně upozad’uje. To vychází z faktu, že se sociálních vědy často až přespř́iliš soustředí na konceptualizace a významy, které studovaným realitám připisují aktéŕi, což však zároveň může znamenat vzdalování se právě oněm studovaným realitám. Symetrizující pohled takové př́stupy kritizuje jako „defenzivní pozici“ (Stöckelová a Brož: 13). I přes tuto částečně oprávněnou kritiku je dle mého názoru určitá míra subjektivace důležitá právě pro vnímání tenze mezi symetrizací a asymetričností realit. Především v závěrečné kapitole proto nechávám vystoupit to, jak proces teritorializace pocitují někteří aktéři prímo na sobě samých. Jedná se o situace, kdy do procesu teritorializace vstoupí konstruktivisticky asymetrické, a tedy jasně definované, orientované a personifikované projevy mocenského postavení (představme si je jako vektory definované konkrétní silou a orientací).

$\mathrm{V}$ tom může být nápomocná především perspektiva konceptu práva na město (Lefebvre 1997, Harvey 2008 a 2012) zasazená do kontextu teritoriálních (re)produkcí. ${ }^{7}$ V nejobecnějším slova smyslu koncept znamená právo a možnost všech obyvatel města prostřednictvím fyzických proměn města měnit i některé mocensko-společenské konfigurace. Ve svém důsledku to (v souladu logikou sociálního konstruktivismu) znamená nést

Harvey navazuje na Lefebvrův esej zasazený do „revolučního“ období před rokem 1968. Zaměření původního Lefebvrova textu vymezuje základní východiska ve smyslu proměny podoby města vlivem proměny jeho společnosti s důrazem na úlohu sociálních hnutí a rovněž urbanistů při citlivém navrhování skutečně inkluzivního urbánního prostředí. David Harvey během posledního desetiletí koncept reaktualizoval zejména $\mathrm{v}$ tom smyslu, že jej obohatil o popis vývoje urbánních prostředí od konce 60. let a zasadil jej do kontextu jevů spojených s vypuknutím globální ekonomické krize $\mathrm{v}$ roce 2008. Harveyho pojetí tak přistupuje ke konceptu práva na město s větším důrazem na analytické ohledání parametrů a důsledků globálního kapitalismu na pozadí jevů, jako jsou financializace, komodifikace, autonomizace atd. (Harvey 2012). 
i zodpovědnost za tyto aktivity a požadavky a jejich dopady. Tento pohled tak umožňuje sledovat proměny města - tedy i rekonfigurace prostoru a jakékoli teritoriální produkce - jako bytostně konfliktní a asymetrizující projevy nárokování a dohledu nad sledovaným prostorem, které se některé skupiny či jednotlivci snaží neustále zvrátit (Susser 1982).

Je nutno podotknout, že $\mathrm{v}$ původním pojetí se koncept zaměřuje především na možnost proměny měst pod vlivem progresivního urbanismu a činnosti sociálních hnutí. Perspektiva Lefebvra i Harveyho může dle mého názoru v tomto ohledu působit poněkud zploštěle, nebot' projevy práva na město lze sledovat i v mnohem fundamentálnějších situacích, tedy pouhým pozorováním jednotlivců či skupin, jejichž nárokování a přivlastňování města může oscilovat mezi vědomostí, bezděčností a (ne)viditelností. Zejména tím široké pojetí práva na město částečně obohacuje symetrizující perspektivu.

Obecně řečeno, ve snaze o ,symetrizaci či souměřitelnost různorodých realit“ (Stöckelová a Brož 2015: 13) se mohou ztrácet individuální př́běhy a významy, jež jsou jedním z konstitutivních prvků nejen etnografického vyprávění, ale i důležitou rovinou lidského uvažování.

V návaznosti na teritoriální (re)produkce, jež jsem během terénního výzkumu na Dlouhých Lávkách pozoroval, v následujících třech podkapitolách a závěru představím, jak je možno výše osvětlené teoretické koncepty analyticky rozpracovat. Podkapitoly, jež jsou označeny římskými číslicemi, představují tři volně související případy prostorových konfigurací, které jsem během zmiňovaných trrí let výzkumu na Dlouhých Lávkách zaznamenal a které je možno nahlížet perspektivou teritoriálních (re)produkcí v kontextu prostorových hranic a bariér - konkrétně klecí na kontejnery na směsný odpad, zdí ve veřejném prostoru a oplocení prostor veřejných institucí. $V$ závěrečné kapitole se pokouším poukázat na to, jak je obtížné některé asymetrie nahlížet pouze perspektivou teritoriálních (re)produkcí ve chvíli, kdy pozorujeme konkrétní dopady prostorové konfigurace (a do ní vtělené moci) na konkrétního jednotlivce.

\section{Sídliště v kleci}

První případ vychází z pozorování, že při rekonfiguraci panelových sídlišt' ve východní Evropě $\mathrm{v}$ posledních pětadvaceti letech hrají zásadní roli procesy privatizace a komodifikace bydlení (Madden a Marcuse 2016). Původní socialisticko-modernistická myšlenka „veskrze společného" na sídlištích ustupuje osobnímu vlastnictví a individualizaci. Bydlení se stává oblíbeným prostředkem výdělku či směny. Samozřejmě že původní společné socialistické zcela nezaniklo, je jen dlouhodobě transformováno a kooptováno režimy individualizovaných posttransformačních procesů. Tuto tendenci definují především teritoriální nároky občanů sdružených do místních společenství vlastníků jednotek (dále SVJ) a bytových družstev (dále BD) ${ }^{8}$ Komodifikace a různé formy přivlastňování se však během let přesunuly z oblasti bytového fondu i do veřejného prostoru. Ilustrativním př́kladem vedoucím $\mathrm{k}$ narušení teritoriální komplexity je instalace mříží kolem popelnic na komunální odpad. Tento druh opatření

8 Zásadní rozdíl mezi těmito dvěma vlastnickými a právními formami je mimo jiné v tom, že člen společenství vlastníků je skutečným osobním vlastníkem bytu(ů) v domě, kdežto družstevník vlastní pouze družstevní podíl, jež je vyjádřen ideální x-tinou celé nemovitosti. 
si v posledních letech získává oblibu zejména na sídlištích. Mezi paneláky jsou na rozdíl od vnitřního města, kde zpravidla není dostatek prostoru na ulici, popelnice na komunální odpad umist’ovány před budovy (do prostor, jež jsou pro tyto účely různou měrou uzpůsobeny).

Současné majetkoprávní poměry v oblasti veřejného prostoru na sídlišti jsou hybridní (re) produkcí původně socialistické konstelace: jsou nárokovány, ale ubránily se formální privatizaci. Nejen v prostředí Účka, ale i na jiných sídlištích v Praze spravuje a vlastní veřejná prostranství z převážné části Magistrát hl. $\mathrm{m}$. Prahy. Zbytek pozemků je různou měrou rozdělen mezi př́slušné městské části a soukromé vlastníky, především restituenty (IPR Praha 2015).

Praxe zamřížování popelnic vyžaduje bud' žádost o specifické povolení, nebo v krajním př́ípadě odkup pozemku. Lokální majetkoprávní subjekty (SVJ a BD) si tak těmito teritoriálními (re)produkcemi formálně nárokují prostory ve veřejném vlastnictví, čímž do značné míry poukazují na určitou nevyhraněnost režimů lokálních konfigurací (srov. Minton 2012).

Méně viditelné je, že oplocením či zamřížováním kontejnerů jsou určité formy teritoriálních (re)produkcí vytěsňovány. Při návštěvě Účka pozorovatele uhodí do očí prostá skutečnost, že na severní straně ulice jsou popelnice volně umístěny v blízkosti chodníku a na jižní straně ulice jsou popelnice situovány do uzamykatelných a kamerou monitorovaných klecí vyrobených z vlnitého plechu a tahokovu. Popelnice v klecích mají výhradně bytové jednotky, jež jsou ve správě SVJ nebo BD. Logika je následující: toto opatření je činěno nejen kvůli obavám z teritoriálního přivlastnění kontejnerů obyvateli z bytů na severní straně ulice, jež vlastní Magistrát hl. m. Prahy ${ }^{9}$, ale také ve snaze eliminovat praxe lidí bez domova ${ }^{10}$. Akční rádius „kontěni““ či „fárání“ (Hejnal 2013; srov. Toušek a Strnadová 2016) místních bezdomovců zahrnuje právě i Účko. Skupinky osob bez př́istřeší, které přebývají v blízkosti nebo v prostoru Dlouhých Lávek (jako i jinde na sídlištích) „,áraji“ za účelem obživy skutečně hojně. Kontinuitu redistribuce a neformální recyklace části odpadu narušila restrikce možnosti vyplácet klienty sběrných surovin $\mathrm{v}$ hotovosti uvedená $\mathrm{v}$ platnost $\mathrm{v}$ roce 2014. I přes tuto restrikci hustá sít' odpadkových kontejnerů na sídlištích stále poskytuje těmto lidem v nouzi ideální př́iležitost, jak využít materiální bohatství sídliště - naleznou zde nejen jídlo, železný či papírový odpad, ale i ošacení a často funkční elektroniku.

Oficiálně jsou důvody uzamykání popelnic artikulovány dvojím způsobem. Za prvé, zájmem o udržování pořádku. Druhým důvodem je snaha, aby do nich nevyhazovali odpad lidé, kteří za svoz z těchto konkrétních popelnic neplatí poplatky. Popelnice tak nejsou jen privatizovány, ale jejich obsah je osazením oplocení cíleně komodifikován - někteří producenti odpadu zamezují tomu, aby se odpad stal dalším prostředkem směny, tedy určité formy (re)produkce. Dochází k tomu, že je v procesu teritorializace kladen důraz na transparentnost

Většina etnických Romů a př́slušníku dalších etnik na Účku žije v magistrátních domech, nicméně i v domech spravovaných a vlastněných SVJ a BD bydlí poměrně nezanedbatelné množství Romu a migrantů.

10 V oblasti sídliště Dlouhé Lávky se dlouhodobě pohybují a různým způsobem zde přebývají desítky lidí, jejichž způsob života by mohl být označován jako bezdomovectví. S některými z nich jsem během výzkumu navázal dlouhodobější kontakt. Jednou z důležitých praktik je pro ně právě „fárání“, jež je v prostředí sídlišt' vzhledem k objemům komunálního i tř́iěného odpadu velmi produktivní činností. 
nakládání s teritoriem a jeho obsahem (Kärrholm 2012). Zamřížování zároveň demonstruje, že odpadky mají pro lokální systém poněkud paradoxní význam. Jejich likvidace je placenou službou, což je transformuje do formy zboží. Představují zvláštně (ne)viditelnou komoditu, která je dle aktérů-vlastníků nevyužitelná pro fungování sídliště, i když má v reálu své další využití díky aktérům-uživatelům, kteří kontejnery prohledávají a využívají je k přilepšení či obživě.

Zamřížování tak představuje teritoriální (re)produkci vycházející z interakce mezi aktéry-vlastníky a aktéry-uživateli a opírá se o oficiální povolení. Tento proces je navíc podmíněn (re)produkcemi ze strany byrokratického aparátu v oblasti správy veřejných prostranství.

Na tomto místě je třeba osvětlit předchozí dva pojmy. Vymezuji dva velmi fluidní a překrývající se konfigurativní aktérské módy operacionalizace sídliště, s nimiž budu pracovat i v průběhu dalšího textu: aktéry-vlastniky a aktéry-uživateli.

Mód aktérů-vlastniků vytváří konfigurace, které vychylují teritoriální komplexitu tím, že svými (re)produkcemi potírají jiné, méně formalizované způsoby přivlastňování, produkované především aktéry-uživateli. Módy aktérů-uživatelů pro změnu svým přivlastňováním prostoru vychylují oficiálně normativní provoz teritoriální konfigurace. Aktéri-vlastníci - tedy situační koalice institucí, samosprávy i místních činitelů a skupin obyvatel sdružených do SVJ a BD se snaží svoje teritoriální nároky „absolutizovat“ a vyřadit ze hry aktéry-uživatele. Tento jev vychází z posttransformační ideologie privatismu (Hirt 2012), projevu teritoriálního přivlastňování par excelence. Privatismus, specifický stav, kdy se osobní vlastnictví stává základním kritériem patřičného společenského postavení, hraje v prostředí sídliště stěžejní roli a ve výsledku spoluurčuje, jaké konfigurace původně nediferencovaného veřejného prostoru zůstanou dostupné pro všechny.

Privatismus (re)produkovaný aktéry-vlastniky i aktéry uživateli je vtělen do systému komodifikace odpadu. Mřǐz potírá odlišné a méně formální logiky teritoriálního přivlastnění. Je tak oslabován původní kolektivistický předobraz fungování socialistického modernistického města, je zamezováno některým méně formálním strategiím recyklace komunálního odpadu a obecně dochází ke snaze o omezování odlišných a netransparentních forem (re)produkce v prostoru.

Instalování mříží pod vnější schodiště u vstupů do panelových domů či odstraňování neprůhledných shluků křovin, představuje podobnou konfiguraci teritoriálních (re)produkcí. Právě důraz na transparentnost veřejných prostranství je prosazován opět především (re)produkcemi aktérů-vlastníků. Nenápadná privatizace veřejného prostoru sídlišt' poukazuje na přetrvávající socialistický aspekt sídlištní teritoriality, jež má kořeny v dobách před rokem 1989 a je usazen v modifikacích (re)produkcí založených na principech, jež Olga Šmídová (1996) popsala jako kvazi-vlastnictví. Kvazi-vlastnictví je popisováno jako komplexní situace, kdy sice oficiálně soukromé vlastnictví neexistuje, nicméně vznikají různé aliance či zájmové a rodinné skupiny, které zdroje společenského či veřejného majetku v podstatě kolonizují svým neformálním, avšak určitým způsobem přednostním právem na jejich užívání. V prostředí sídliště Dlouhé Lávky to konkrétně znamená, že v některých sousedstvích se neformální kvazivlastnické koalice, jejichž organizačními platformami jsou dlouhodobě usazené majetkoprávní struktury vycházející ze socialistických i posttransformačních způsobů sdružování, udržují i po více než 28 letech. Tyto koalice však v současnosti své kvazivlastnické nároky 
neuplatňují na bytový fond (protože většina z něj již byla privatizována), ale na (veřejný) prostor sídliště jako celek.

Od popelnic se tedy posouváme k veřejnému prostoru. Během let 2014-2017 jsem na Dlouhých Lávkách opakovaně zaznamenával a pozoroval důvody a dopady odstraňování laviček, prořezávání neprůhledných křovisek a nízkých dřevin a zároveň o těchto skutečnostech diskutoval s místními aktéry-vlastniky i aktéry-uživateli Tyto praxe se děly především na objednávku poměrně nepočetné (avšak z hlediska teritoriální (re)produkce vlivné) koalice aktérů-vlastníků. Situace je o to zajímavější, že mobiliář sídliště nebyl díky časové situovanosti jeho dostavby do let 1989 až 1991 plně dokončen. Po několika intervencích vedoucích k odstranění zbývajícího rekreačního a odpočinkového vybavení veřejných prostranství se z některých míst staly nevyužívané prostory, jejichž další osud je předmětem lokálních diskusí. Aktivní proměna je zatím definována pouze v rovině nerealizovaných strategií, tedy nezávaznými koncepčními dokumenty městské části (Strategický plán, Kulturní strategie).

Tato historicky ukotvená (re)produkce teritoriality podmiňuje sekuritizaci, transparentnost a vytvář́ specifickou asymetrii v prostoru sídliště, jejíž dosah vede až $\mathrm{k}$ voleným zastupitelům městské části a možnosti ovlivnit hmotnou podobu sídliště směrem $\mathrm{k}$ regulaci i výměně vybavení veřejného prostoru.

Paradoxně právě na vyprázdněnost a nevyužívanost veřejných prostranství si přitom aktérí-vlastníci, jejichž stížnosti způsobily vyprázdnění prostoru, sami stěžují. Místní samospráva, zejména pak úředníci Odboru dopravy a životního prostředí městské části i organizace zastupující Magistrát hl. m. Prahy, tedy především Technická správa komunikací, a. s., jež má na starosti údržbu veřejných prostranství ve vlastnictví hlavního města, se dají v tomto ohledu považovat za poctivé vykonavatele oficiálně normativního př́istupu $\mathrm{k}$ péči o veřejná prostranství.

Mohlo by se zdát, že je tak lokální konfigurace teritoriálních (re)produkcí zablokována. Při delším pozorování - a mém spolupraktikování pobytu a pohybu v prostorové konfiguraci sídliště spolu s aktéry - se však ukázalo, že se projevy teritoriálního přivlastňování místních aktérů-uživateli̊, v tomto př́padě zejména místní mládeže a částečně i lidí bez domova, posunuly do míst, jež jsou z normativního hlediska pro aktéry-vlastniky obtižně uchopitelná. Aktérí-uživatelé tak neustále „vrací úder“ prostřednictvím (re)produkce hranic toho, co je možno za veřejný prostor vůbec považovat.

\section{Veřejné soukromí: Existuje správná strana zdi?}

Přivlastňování prostor, které na první pohled nemají využití, jméno, často ani definici, je tedy dalším specifickým prípadem teritoriálních (re)produkcí. Tyto (re)produkce jsou pro městkou krajinu - a především pro modernistická sídliště ${ }^{11}$ - častou skutečností, kterou nazývám prostorovou potencialitou (Lehečka 2013 a 2015). Tato potencialita spočívá v nevyhraněnosti, variabilitě prostoru a jeho specifické toponymii (Bazac-Billaud 2000). Do hry vstupuje také

11 Procentuální poměr veřejného proti soukromému či polosoukromému prostoru je v sídlišti podle Institutu plánování a rozvoje hlavního města Prahy 70 \% ku $30 \%$ ve prospěch veřejných prostranství. Ve vnitřní Praze, zejména ve čtvrtích s blokovou zástavbou, je tomu přesně naopak. 
př́rodní diverzita a značné množství organicky vzniklých přírodních zákoutí. Krajina sídliště je neustále se měnícím socio-materiálním prostředím překrývajících se kontextů usazených v „přrírodních“ prostranstvích. Sídliště je svého druhu parkem, který se dynamicky mění v souladu s prŕrodními cykly a jevy. Sídliště není ani městem, ani přírodou. To je asi nejrazantněji vidět na tom, jak dramaticky se mění vizuální a hmotový charakter sídliště v zimních a letních měsících, nebo jakým způsobem jsou lokální sítě pěšin a jejich užití ovlivňovány suchem či deštěm. Takové prostředí konfiguruje teritoriální těla (Kärrholm 2012: 54), tedy prostorové zkušenosti vtělené do pohybu a tělesnosti jednotlivců či skupin. Tyto vtělené zkušenosti jsou vytvářeny (re)produkováním prostoru a jsou jednoduše řečeno výsledkem interakce mezi aktéry a důležitými složkami socio-materiálního prostředí.

Někteří aktéři-uživatelé, kteří byli dlouho vytlačováni z exponovaných prostor, si na Dlouhých Lávkách teritorializovali místo, kde je opěrná zed' zadržující svah před jedním z panelových domů. Okolní nevyhraněný prostor je většinou lidí považován za pouhé křoví nad betonovou zdí. Jenže situace je komplexnější. V prostoru, kde se vyrovnává původně strmý svah zadržovaný opěrnou zdí, si skupinky místní mládeže během let vytvořily „bezpečné“ místo za zdí, které se vymyká všem ostatním prostorům, ze kterých byly v předchozích př́padech vytlačeny.

Druhá strana zdi se vymyká především tím, že je velmi těžko dostupná. Přístupová cesta sem vede po př́krém svahu podél západního lemu opěrné stěny, nebo „tunelem“ z křovin vedoucím od chodníků asi dvacet metrů nad prostorem.

I přes specifickou „nedostupnost“ je místo paradoxně poměrně exponované, nebot’ se nachází jen pár metrů od severního průčelí jednoho z panelových domů. Konfiguračně je toto průčelí př́větivé tím, že díky dispozici panelových domů obsahuje pouze kuchyňská okna jednotlivých bytů. Na aktéry-uživatele pohybující se v tomto prostoru je navíc vidět i z prostorů přilehlých komunikací. Z hlediska (re)produkce tak toto místo poskytuje paradox veřejného soukromí. Toto situační veřejné soukromí má několik charakteristik. Jeho podstata se rozpíná mezi sdíleností společných prostranství (prostorovou, sociální i např. smyslovou) a pohodlností a navozováním intimity soukromých, nerušených míst. Charakteristiku veřejného soukromí pro sídlištní děti a mládež naplňují mimo tohoto prostoru na Dlouhých Lávkách také např́klad některé sevřené vnitrobloky, opuštěná dětská hřiště či odpočinkové zóny v místním hypermarketu.

Druhá strana zdi umožňuje skupinám aktérů-uživatelů poměrně nerušeně existovat a zároveň mít pocit, že je tak trochu součástí okolního prostoru. Dobrý rozhled je klíčový, nejen kvůli přehledu nad tím, co se na sídlišti děje, ale i pro př́ípad, že by bylo třeba rychle zmizet. Př́ikrý svah zároveň poskytuje bezpečí. Aktéři-vlastníci totiž přístup k místu nepovažují za schůdný. Navíc je nutno připomenout, že prostor z hlediska většiny ostatních modalit aktérství v prostoru sídliště není považován za místo hodné návštěvy, nebo je dokonce považován za nebezpečný. Takto (re)produkované veřejné soukromí splňuje velmi důležitou charakteristiku - pokud je lokální skupinka aktéri̊-uživateli̊ (zejména dětí a dospívajících) př́itomna, nikdo jiný si sem netroufne vstoupit. Veřejné soukromí na druhé straně zdi tak v určitém čase a prostoru vytváŕí pocit obrácené dichotomie vztahů oficiálně-normativní / lokálně-neformálně-normativní. Druhá strana zdi funguje podle nevyřčených pravidel konkrétní konfigurace aktérů-uživateli̊. Místo tak situačně spoluprodukuje specifický slang místní mládeže, či větší benevolenci vůči některým problematickým aktivitám - drogy, alkohol atd. 
V souladu Kärrholmovým pojetím má druhá strana zdi i jiné režimy teritoriality. Formy (re)produkce jsou zde sice asymetrické, ale stále zmnožené. Mimo období, kdy jsou př́tomni mladiství, je místo např́íklad navštěvováno živočichy, lidmi bez domova, místními sociálními pracovníky nebo - sociálním antropologem. Tito jiní aktérí-uživatelé je navštěvují za účelem obživy nebo nepřímého monitorování praktik místních dospívajících - činnosti rekonstruují zejména z odpadků a věcí odhozených v bezprostředním okolí místa (použité prezervativy, injekční stř́kačky, špačky od marihuanových cigaret, lahve od alkoholu apod.).

Druhá strana zdi v di̊sledku poskytuje vhled do (ne)viditelné a často stigmatizované roviny lokálních praktik a režimů teritoriálního přivlastňování některých zákoutí sídliště. Druhá strana zdi není jen důsledkem vytlačování a proměn fungování veřejného prostoru, ale rovněž představuje projevy imaginativního př́stupu k povaze veřejných prostranství na sídlišti, kdy se z místa, jež mělo původně pouze funkčně statický charakter, stalo (re)produkované teritorium proměňující podobu lokální komplexity. Druhá strana zdi je veřejným soukromím, místem, které vytváŕí z aktérů-uživatelů alespoň na chvíli aktéry-vlastníky. Je alternativně-normativním výsledkem imaginace a praxe, je „lefebvrovskou heterotopií“ (Lefebvre 1996, Harvey 2012), tedy místem, kde jsou jiné světy možné, Druhá strana zdi je lokálním projevem práva na město, barikádou, zpoza níž se dá vždy přeskočit do normativního světa.

\section{Pocity plotu}

V poslední empirické podkapitole se pokusím poukázat na třetí prípad teritoriální (re)produkce. Od druhé stany zdi se přesuneme k plotu, ke konfiguraci, jež je té předchozí blízká (jak tematicky, tak prostorově) a zvyšuje ilustrativnost situace $\mathrm{z}$ terénního přepisu v úvodu textu. Jedná se o úsek procesu teritoriální (re)produkce, jehož jsem se stal do určité míry účastníkem díky svému zapojení do projektu animace veřejného prostoru pro děti a mládež. Tento př́pad je zároveň ošemetný, protože některé níže popisované (re)produkce by bylo možno na první pohled definovat jako vandalismus. Daleko více však chci ilustrovat skutečnost, že mohou mít i jiný význam. V souladu s teoretickými východisky tvrdím, že aktéri-uživatelé se (re)produkcemi, které se vymykají normativní povaze fungování provozu, tedy tomu, co by Kärrholm přirovnal k teritoriálním strategiím a taktikám, pokoušejí zvrátit a vychýlit aktuální teritoriální konfigurace. Uplatňují svoje právo na město (sídliště) tím, že jej proměňují prostřednictvím sebe sama a tím zvýznamňují důležitost absence překážek a operativního, fluidního a imaginativního pojetí hranic, ke kterému struktura veřejných prostranství sídliště v určitém ohledu svádí.

Př́ikladem (re)produkce struktury prostoru, jež byla ve svých kořenech definována neosobní silou, $\mathrm{v}$ tomto prípadě strategiemi architektů a majetkových poměrů, je plot, který je jen pár metrů od v úvodu popisovaného oploceného hřiště na Účku a lemuje zahradu základní školy, na které je hřiště umístěno. Oplocení školní zahrady dlouhodobě vytváří důležitou bariéru v prostoru. Z požadavku místních obyvatel je zahrada otevřena 24 hodin denně, nebot' přes ni prochází poměrně důležitá pěší komunikace. Do zahrady však ústí pouze tř̌i vchody v ne zcela vyhovujících místech. Pro některé aktéry-uživatele tak plot školní zahrady má v prostředí Účka jedinou roli - je vnímán jako zbytečná překážka. Normativita a vlastnická práva tak podmínila teritoriální konfiguraci, která je z hlediska přivlastňování obyvatel 
důvodem k nenápadné demonstraci, že hranice každodenního fungování prostoru jsou vyjednávány i jinak, totiž že režimy hranic mohou být (re)produkovány na základě narušování a zpochybňování těchto hranic. Režim pohybu aktéri̊-uživatelü tak operacionalizuje jakýkoli plot v okolí jako nemístnou překážku, jejíž narušení neznamená jen fyzické překonání bariéry, ale implicitní odmítnutí strukturace prostoru.

Ve zmiňovaném oplocení školy bylo v průběhu času vytvořeno několik ,otvorů“ ve strategických místech tak, aby byl prrístup na hřiště od paneláků co nejkratší. Nejviditelnějším a z běžného pohledu nejparadoxnějším prríkladem je tzv. plot němých nářků, což je výzkumný název pro část plotu, na kterém je přivlastnění demonstrováno nejviditelněji a nejasněji. Výzkumný název nevychází z lokálního názvosloví, nebot' aktéři-uživatelé daný plot nepovažují za něco, o čem by se mělo hovořit, či to dokonce jakkoli pojmenovávat.

V plotu němých nářků bylo během let vytvořeno (pilkou na železo) několik otvorů (v jednu chvíli však vždy pouze jeden), jejichž účelem je zkrátit a zpřímit cestu na hřiště zhruba o sto metrů. Otvor je následně hojně využíván a aktéři-uživatelé procházejí na hřiště zpravidla právě tudy, nebot' oficiální cesta na hřiště branou do školní zahrady je zhruba o 100 metrů delší. O původci otvoru se nikdy nemluví, všichni jej ale využívají (i já). Po čase je absence příčle vyřešena navařením nové tyčoviny do příslušného pole plotu. Po opravě se vytvoření otvoru brzy opakuje. Pracovníci správy školy plot opakovaně uvádějí do původního stavu, aby jej následně „,někdo“ opět zprostupnil. Navíc je často vyříznuta jiná, dříve nedotčená př́čel. Plot tak dnes při bližším pohledu hraje různými odstíny červené barvy. V jednom př́padě (červen 2016) dokonce došlo k provizornímu zadrátování otvoru hliníkovým vázacím drátem. Zprvu se zdálo, že jde o rezignaci správy, nicméně po čase byl otvor tradičně zavařen.

Aktéři-vlastníci, tedy správa školy (zaštit’ující se vlastnickými právy i provozním a bezpečnostním řádem školy), si tak znovupřivlastňují plot reakcí na teritoriální přivlastňování prostoru aktéry-uživateli. Díky tomu vidíme, že teritorialitu skutečně nelze chápat jinak než jako proces, který se projevuje v čase a prostoru různě se překrývajícími (re)produkcemi. Obecná logika praxe připouští - mimo „dobré správy“ a dohledu nad provozním řádem ze strany správce - také vyrážet zámek branky od hřiště, přelézat čtyřmetrový plot (viz výše) nebo za pomoci štípacích kleští odstraňovat nýty z výdřevy oplocení hřiště (za účelem vstupu).

Takové teritoriální (re)produkce mají jasnou časoprostoru povahu - tady a ted', jsou performancí i zhmotněným požadavkem - neformálním, konfliktním, avšak neviditelně kolektivním socio-materiálním projevem práva na město ve smyslu: my chceme projít tudy, když to konstrukce plotu a naše prostředky umožňují.

Neformální požadavek aktérů-uživateli̊, tedy především dětí, mládeže, ale i některých dospělých, po prostupném veřejném prostoru má rovněž odlišnou časovost než projevy přivlastňování ze strany školy či správce sportovního areálu. Jinými slovy, strukturace prostoru (tedy jak plotu, tak hřiště) a jeho normativní časový rámec dostatečně nereaguje na instrumentální, imaginativní a proaktivní (re)produkce jeho nej(ne)viditelnějších aktérư-uživateli̊, a tak si tito aktéři svými (re)produkcemi berou některé části sídliště zpět.

Potřeba jednat tady a ted' je ještě posilována tím, že normativní teritoriální (re)produkce tedy oficiální provozní dobu hřiště a provozní řád - v době pozorování striktně nedodržuje ani původní správce (červen 2015). Popření pravidel prostoru je (srov. Stulíková 2015) př́kladem přivlastnění par excellence, i když z hlediska oficiálních strategií byly tyto a jim podobné 
jevy většinou považovány za projev dezorganizace. Dezorganizace je vidět na všech stranách, a tak prostorová konfigurace tenduje k situaci, kdy za nedodržování pravidel není nikdo trestán. Původci díry v plotě zůstávají oficiálně neznámí, nedůslednost a nedochvilnost správce je předmětem debat pouze na oficiální úrovni. Aktéři-uživatelé si poradí i bez správce. Jinými slovy, konkrétní projevy teritoriálních (re)produkcí v podobě odstraňování překážek i nedodržování provozního řádu (uživateli i správcem) zůstávají neosobní, (ne)viditelné a nesankcionova(tel)né.

\section{"Závěr“: Personifikovaná vina}

V předchozích třech podkapitolách byly představeny případy teritoriálních (re)produkcí, jež jsem na sídlišti Dlouhé Lávky během let vypozoroval, zaznamenal a analyticky zpracoval ve snaze o popis různorodých realit, které na sídlišti (re)produkují prostorové konfigurace. I přes nesmírně produktivní (a)symetrizující analytický rámec je třeba podotknout, že předchozí analýze uniká jedna skutečnost - individuální osudy konkrétních aktérů-vlastníků a aktérů-uživateli̊. Proto nyní zkusím perspektivu zaměřit na konkrétního jednotlivce, a vpustit tak do hry více subjektivního rozměru vnímání (re)produkce teritorií.

Na podzim roku 2015 došlo v prostorové konfiguraci na Dlouhých lávkách k nenápadné dílčí změně. Zčásti i díky mé přímluvě a nekonečným stížnostem ze všech stran se správcem hřiště stal představitel aktérů-uživatelů z přilehlého paneláku. Dino, sedmadvacetiletý otec malé dcerky a celoživotní obyvatel Dlouhých Lávek, toho času pracující jako vedoucí prodejní sekce v hypermarketu, vstoupil do nevyhovujícího provozu zdejšího hřiště s aktivní iniciativou propagující potřebu lokální správy hřiště. Záhy po jeho nástupu se začaly projevovat změny ve formě uplatňování provozního řádu a dalších normativních zásad ve vztahu k prostoru hřiště a jeho okolí. Období Dinovy správy s sebou přineslo optimalizaci a na první pohled hladké fungování hřiště, především v odpoledních hodinách. Přesněji řečeno, konfiguraci ovlivnilo velice zásadní vychýlení, kdy Dinův (ne)formální přístup ke správě, vycházející ze znalosti a vtělenosti teritoriálních (re)produkcí aktérů-uživatelů, nabyl v podstatě normativní povahy. Přechod do Dinova režimu spočíval především v rozšíření provozních hodin v letních měsících směrem k západu slunce. Normativní řád tedy kooptovala jiná forma časovosti (nezávislá na zaměstnanci správy přijíždějícím z jiné čtvrti) a provozní hodiny hřiště se tak prakticky měnily ze dne na den. Dino, jehož matka je Romka, navíc souběžně založil futsalový oddíl, který si zdejší hřiště zvolil jako svoje domácí. Vytvoření historicky prvního futsalového oddílu na Dlouhých Lávkách vedlo k vychýlení komplexity ve prospěch lokální etnicky smíšené komunity, tím ale paradoxně učinilo místní aktéry-uživatele daleko viditelnějšími.

Díky oficiálním přímluvám lokálních sociálních organizací (sociální pracovníci, mezi nimiž jsem byl i já, a tudíž nesu za toto vychýlení svi̊j díl odpovědnosti) byl ze strany aktéri̊-vlastniki̊, tedy školy, správce hřišt' i městské části, Dino považován za garanta zajištění naplňování normativních regulí vztahujících se k provozu školního hřiště, tím ale zároveň jako jeden z dlouhodobých aktérů-uživatelì opustil svoji auru nepostižitelnosti.

Dino ihned po nástupu do funkce začal neformálně porušovat některá - z jeho pohledu -nadbytečná pravidla: rozsvěcoval lampy nad hřištěm dříve či potají půjčoval klíče ostatním aktériom-uživateliom tak, aby provoz hřiště nebyl závislý jen na jeho přítomnosti. Tato 
rekonfigurace lokálního režimu vedla - mimo produktivnějšího fungování a částečného od-komodifikování hřiště - $\mathrm{k}$ razantním proměnám Dinovy pozice v průběhu následujícího roku. $\mathrm{Na}$ jedné straně se pro některé aktéry-uživatele proměnil v nejednoznačného člověka, protože se jeho původně neformální role stala prakticky formalizovanou. Dino se tak pro mnohé stal součástí normativního aparátu, a dokonce začaly kolovat fámy o jeho snaze se prostřednictvím hřiště obohatit. Perspektivou správy školy i hřišst počal být na straně druhé nahlížen jako člověk nedodržující a narušující normativní provoz svěřených prostor. Situace se razantně počala zhoršovat, když organizace soukromého provozovatele hřišt', jež Dina jako správce zaměstnávala, $v$ průběhu roku 2016 na místě přestala působit. Navíc se zhruba v této době změnilo i vedení školy. Zástupci školy zakázali poměrně volné využivání nočního osvětlení hřišt’ a Dino se dostal do situace, kdy po něm škola chtěla peníze za odehrání zápasu i přes to, že tým oficiálně podporovala městská část, která stavbu hřiště financovala. Je nutno dodat, že pro členy Dinova oddílu představovala platba za hřiště mnohdy nepřekonatelný problém.

Vychýlení provozu hřišt' směrem k tzv. komunitní správě tak ve výsledku vedlo k tomu, že Dino vystoupil z (ne)viditelnosti jako představitel specifické sféry teritoriálních (re)produkcí, které často překračují logiku fungování normativních regulí. Systém se vychýlil a posunul do nové konfigurace.

Vidíme, že pokud se pokusíme sledovat trajektorii jedince, teritoriální komplexita se poněkud rozmývá a do popředí vystupuje subjektivita a asymetrizace vztahů. Dinova činnost narušila a stále narušuje teritoriální rámce: správa školy se měla konečně na koho obracet ohledně nedodržování všeobecného normativního rámce fungování. Lokální neformálně-normativní rámec se sice neoficiálně stal součástí provozního řádu prostoru, Dino se tak ale zároveň dostal do permanentního ohrožení prostřednictvím přímého sankcionování jeho osoby jako představitele aktérů-uživateli̊.

Pod vlivem všech problémů a tlaků Dino ve funkci správce hřiště v roce 2016 skončil. Byl dokonce nucen přesunout místo konání domácích zápasů svého týmu mimo Dlouhé Lávky.

Jak s tímto evidentně mocensky podmíněným odklizením aktéra-uživatele naložit? Naprííc celým textem jsem se pokusil nastínit, že optika teritoriálních (re)produkcí (Kärrholm 2012) může být velmi produktivní a že prostorové překážky mohou poodhalit méně zjevné procesy ustavování lokálních prostorových konfigurací. Mříže na kontejnery, opěrné zdi a ploty, ale i prostý fakt neprůhlednosti nebo naopak vyprázdněnosti veřejného prostoru mohou představovat instrument pro nahližení interakce normativních teritoriálních (re)produkcí („,provozní řády“, privatismus, kvazivlastnictví, komodifikace) a přivlastňování prostoru sídliště jeho (ne)viditelnými uživateli. Tato v mnohém symetrizující perspektiva ukazuje, že pokud nahlížíme teritorializaci jako proces vytvářený spolupůsobením mnoha živých i neživých aktérů, při jehož pozorování nelze snadno určit, kdo a co prostoru vládne, je viníkem, vítězem či poraženým, můžeme dojít k velmi zajímavým analytickým zjištěním.

Symetrizace naráží na určité potíže ve chvíli, kdy v konfiguraci necháme vystoupit do popředí subjektivitu určitého člověka v konkrétním výseku časoprostoru (Dino). Začneme totiž sledovat osobní motivace, jednání, sympatie i antipatie a další přidružené pocity, tedy 
asymetrizující (re)produkce, jež jsou v konkrétních chvílích z hlediska teritoriální komplexity nepř́liš důležité. Tehdy nezbývá než se vrátit zpět $\mathrm{k}$ jednotlivci a proměnit optiku a zapojit perspektivu mocenského pole, tedy provést ,analýzu“ vztahů, avšak vidět je jako pouhé dočasné síly, okamžiky, jež byly vyextrahovány z onoho nekončícího procesu teritorializace. Do závorky tak vytkneme otázku: Proč se Dino v důsledku ztráty anonymity stal symbolickým původcem všech projevů teritoriálních přivlastnění činěných aktéry-uživateli? Odpověd’ pomocí teritoriálních (re)produkcí by zněla zhruba takto: Protože se do určité míry stal dočasným vtělením všech dosavadních zničených plotů, vyražených zámků, odštípnutých výdřev a čehokoli dalšího, co v normativním rámci lokální konfigurace představuje - byt' nenápadné - vychýlení. Jako nekonečné oběti subjektivity, lidé z masa a kostí, ale zakoušíme působení mocenských vztahů spíše asymetricky, díky čemuž zároveň podprahově tušíme, že tehdejší Dinův názor na celou věc byl úplně jiný - situaci interpretoval především jako velkou křivdu, etnickou diskriminaci a snahu odstavit jej od zdrojů, tedy vzít mu jeho právo na město. Právě rozdílnost a současná adekvátnost obou pohledů by měla být stále brána $\mathrm{v}$ potaz.

Časoprostor se neustále rekonfiguruje a dnes už je všechno trochu jinak. Pocity v lidech i plotech se ale dál usazují.

\section{Literatura}

BAZAC-BILLAUD, Laurent. 2000. „Jihozápadní město, Praha 13, Lužiny: Několik zamyšlení nad zásadní otázkou pojmenování nevyhraněného prostoru.“ Pp. 51-72 in Laurent BAZAC-BILLAUD a Zdeněk UHEREK (eds.). Cahiers du Cefres, No. 18: Slova města. Praha: CEFRES.

BOURDIEU, Pierre. 1990. The Logic of Practice. Stanford: Stanford University Press.

BOURGOIS, Phillipe. 2003. In Search of Respect. Selling Crack in El Barrio. Cambridge: Cambridge University Press.

BRIGHENTI, Andrea M. 2010. „On Territorology, Towards a General Science of Territory.“ Theory, Culture and Society 27(1): 1-21.

BROWN, D. Steven a Rose CAPDEVILA. 1999. „Perpetuum Mobile: Substance, Force and the Sociology of Translation." Pp. 26-50 in John LAW and John HASSARD (eds.). Actor Network Theory and After. Oxford: Blackwell Publishers/Sociological Review.

BROŽ, Luděk a Tereza STÖCKELOVÁ. 2015. „Symetrie je často stranická: rozhovor se Zdeňkem Konopáskem.“ Cargo 13(1-2): 117-132.

CASTELLS, Manuel. 1972. City, Class and Power. New York: St. Martin's Press.

HARVEY, David. 2000. Spaces of Hope. Los Angeles: University of California Press.

HARVEY, David. 2008. „The Right to the City.“ New Left Review 53: 23-40.

HARVEY, David. 2012. Rebel Cities: From the Right to the City to the Urban Revolution, London: Verso Books.

HEJNAL, Ondřej. 2013. „Já si je najdu, ty vole. Dyt’ máme furt stejný místa: Místa bezdomovců ve veřejném prostoru." Lidé města 15(3): 419-441.

HIRT, Sonia A. 2012. Iron Curtains. Gates, Suburbs and Privatization of Space in the Post-Socialist City. Oxford: Wiley-Blackwell.

HOLSTON, James. 1989. The Modernist City. An Anthropoligical Critique of Brasilia. Chicago: University of Chicago Press. 
IPR Praha. 2015. Koncepce rozvoje veřejných prostranství pražských sídlišt'. Praha: Institut plánování a rozvoje.

KÄRRHOLM, Mattias. 2007. „The Materiality of Territorial Production: A Conceptual Discussion of Territoriality, Materiality, and the Everyday Life of Public Space." Space and Culture 10: 437-453.

KÄRRHOLM, Mattias. 2012. Retailising Space. Architecture, Retail, and the Territorialization of Public Space. London, England: Ashgate.

KPMG. 2016. Voice of Real Estate. Bytový fond hlavního města Prahy a jednotlivých městských částí. Praha: KPMG.

LATOUR, Bruno. 2003. Nikdy sme neboli moderní: esej o symetrickej antropológii. Bratislava: Kaligram.

LEFEBVRE, Henri. 1991. The Production of Space. London: Wiley-Blackwell.

LEFEBVRE, Henri. 1996. „The Right to the City.“ Pp. 63-181 in Eleonor KOFMAN a Elisabeth LEBAS (eds.). Writings on Cities. Cambridge, Massachusetts: Wiley-Blackwell.

LEHEČKA, Michal. 2013. „Sídliště současné a minulé. Proměny pražského sídliště Stodůlky očima jeho obyvatel.“ Slovenský národopis 61(4): 351-367.

LEHEČKA, Michal. 2015. „Když nám tam chtěl někdo hrát, tak jsme ho třeba vykamenovali: Reflexe vtělené zkušenosti vyrůstání na sídlišti.“ Biograf 61(2): 35-62.

LOW, Setha a Daniel LAWRENCE-ZUNIGA. 2003. Anthropology of Place and Space. Oxford: Blackwell.

LOW, Setha, Dana TAPLIN a Suzanne SCHELD. 2005. Rethinking Urban Parks: Public Space and Cultural Diversity. Austin: The University of Texas Press.

LOW, Setha. 2017. Spatializing Culture: The Ethnography of Space and Place. New York, London: Routhledge.

MADDEN, David a Peter MARCUSE. 2016. In Defense of Housing. London: Verso Books.

OUŘEDNÍČEK, Martin a Jana TEMELOVÁ. 2012. Sociálni proměny pražských čturtí. Praha: Academia.

MINTON, Anna. 2012. Ground Control. Fear and Happiness in Twenty-first Century City. London: Penguin Books.

NĚMEC, Michal a Tomáš BRABEC. 2015. Analýza vývoje sociální struktury velkých pražských sídlišt' mezi lety 2001-2011. Praha: Institut plánování a rozvoje.

PELS, Dick. 1996. „The Politics of Symmetry.“ Social Studies of Science 26: 277-304.

PŘIDALOVÁ, Iva a Martin OUŘEDNÍČEK. 2017. „Role zahraniční migrace v měnící se sociálně-prostorové diferenciaci Prahy.“ Sociologický časopis/Czech Sociological Review 53(5): 659-692.

RABINOW, Paul. 1989. French Modern. Norms nad Forms of Social Environment. Chicago: University of Chicago Press.

STEVENS, Quentin. 2008. Ludic City. Exploring the Potiential of Public Spaces. New York: Routhledge.

STÖCKELOVÁ, Tereza a Luděk BROŽ. 2015. „Př́sliby a úskalí symetrie: Sociální vědy v zemi za zrcadlem." Cargo 13(1-2): 5-33.

STULÍKOVÁ, Vlasta. 2015. „Od veřejného ke sdílenému prostoru: Městský park v symetrické perspektivě.“ Cargo 13(1-2): 67-94.

SUSSER, Ida. 1982. Norman Street. Poverty and Politics in an Urban Neighborhood. Oxford: Oxford University Press.

ŠMÍDOVÁ, Olga. 1996. „Vlastnictví a kvazi-vlastnictví bytů za socialismu a jejich postsocialistická mutace." Pp. 116-124 in Anne OLIVIER (ed.). Cahiers du CEFRES. $N^{\circ} 11$, Pưvodní a noví vlastníci. Praha: CEFRES. Citováno 10. dubna 2018 (https://www.researchgate.net/publication/292751683 Vlastnictvi_a_kvazi-vlastnictvi_za_socialismu_a_jejich_postsocialisticka_mutace).

TAUSSIG, Michael. 1984. „Culture of Terror, Space of Death. Roger Casement's Putumayo Report and the Explanation of Torture." Comparative Studies in Society and History 26(3): 467-497. 
TOUŠEK, Laco a Lenka STRNADOVÁ. 2016. „What's ,Out of Place“? Intolerance in Public Space.“ Pp. 201-223 in David WEBERMAN a Stefano MORONI (eds.). Space and Pluralism. Budapest: CEU Press.

WACQUANT, Löic. 2008. Urban Outcasts: A Comparative Sociology of Advanced Marginality. Cambridge: Polity.

\section{Autor}

Michal Lehečka působí na Fakultě humanitních studií Univerzity Karlovy. Ve své akademické práci se zabývá fenomény spojenými s územním rozvojem, prostorovou segregací, právem na město a především pak problematikou vývoje socialistických modernistických měst (panelových sídlišt') v kontextu (re)produkce prostoru. Jako člen spolku Anthropictures se rovněž věnuje aplikovaným výzkumům v oblasti migrace, městského plánování a rozvoje veřejných prostranství.

Kontakt: leheckam@seznam.cz 